\title{
Anti-PD-1 Monoclonal Antibody BI 754091
}

National Cancer Institute

\section{Source}

National Cancer Institute. Anti-PD-1 Monoclonal Antibody BI 754091. NCI Thesaurus.

Code C132252.

A monoclonal antibody directed ag ainst the negative immunoregulatory human cell surface receptor programmed cell death protein 1 (PD-1; PDCD1), with immune checkpoint inhibitory and antineoplastic activities. Upon administration, BI 754091 selectively binds to and blocks the activation of PD-1, an immunog lobulin (Ig) superfamily transmembrane protein, by its ligands programmed cell death ligand 1 (PD-L1), which is overexpressed on certain cancer cells, and programmed cell death ligand 2 (PD-L2), which is primarily expressed on antigen-presenting cells (APCs). This results in the activation of T-cells and T-cell-mediated immune responses against tumor cells. Activated PD-1 negatively regulates T-cell activation and plays a key role in in tumor evasion from host immunity. 